\title{
MANAJEMEN KINERJA GURU RAUDHATUL ATHFAL (RA) BERPRESTASI DI YOGYAKARTA
}

\author{
Fu'ad Arif Noor \\ STPI Bina Insan Mulia Yogyakarta \\ Email: fuadarifn@stpi-bim.ac.id \\ Orcid ld: 0000-0002-2199-4564
}

Article received: 28 Desember 2019, Review process: 06 Januari 2020

Article published: 30 Maret 2020

\begin{abstract}
This research was conducted to find out what $R A$ achievers have done so that they can inspire other teachers, with a qualitative method of psychological approach that is carried out directly on the subject under study, in order to obtain all data relating to the performance management of outstanding teachers so that in managing their performance they become teachers an example for fellow teachers. Data collection uses interviews, documentation, and observation. Data analysis techniques include reducing data, presenting, drawing conclusions and verifying. Data validity test is done by triangulation techniques. The research succeeded in revealing the performance of RA achievers in Yogyakarta, there were 6 (six) steps taken by RA achievers, namely: 1) Knowing that there were still deficiencies in performance, 2) Recognizing weaknesses and deficiencies in the seriousness of teaching, 3) Identifying what was the cause first drawbacks related to the performance itself, 4) Developing the performance plan presented, 5) Assessing the problem has been resolved or not (problem solving), and 6) Starting from the beginning again, if needed and needed again.
\end{abstract}

Keywords: Management, performance, RA teacher, achievement

\begin{abstract}
Abstrak
Penelitian ini dilakukan untuk mengetahui apa saja yang dilakukan guru RA berprestasi agar dapat menginspirasi pada guru yang lainnya, dengan metode kualitatif pendekatan psikologis yang dilakukan langsung kepada subjek yang diteliti, guna memperoleh semua data yang berkaitan dengan manajemen kinerja guru berprestasi sehingga dalam pengelolaan kinerjanya menjadi guru teladan bagi sesama guru. Pengumpulan data menggunakan wawancara, dokumentasi, dan observasi. Teknik analisis data meliputi mereduksi data, menyajikan, menarik kesimpulan dan menverifikasi. Uji keabsahan data dilakukan dengan teknik triangulasi.Penelitian berhasil mengungkapkan kinerja guru RA
\end{abstract}


berprestasi di Yogyakarta ada 6 (enam) langkah yang dilakukan oleh guru RA berprestasi yaitu: 1) Mengetahui masih ada kekurangan dalam kinerja, 2) Mengenal kelemahan dan kekurangan dalam keseriusan mengajar, 3) Mengidentifikasi perihal apa yang merupakan penyebab kekurangan terlebih yang behubungan dengan kinerja itu sendiri, 4) Mengembangkan rencana kinerja yang tersaji, 5) Melakukan penilaian masalah tersebut sudah teratasi ataukah belum (problem solving), serta 6) Memulai dari awal lagi, apabila diperlukan dan dibutuhkan kembali.

Kata Kunci: Manajemen, kinerja, Guru RA, berprestasi.

\section{PENDAHULUAN}

Alfred North Whitehead mengemukakan tentang pendidikan dan faktor yang mempengaruhinya bahwa pendidikan adalah perolehan seni mutakhir pengetahuan. Prosedur terbaik akan bergantung pada beberapa faktor yang tidak bisa diabaikan, yaitu, jenius guru, tipe intelektual murid, prospek hidup mereka, peluang yang ditawarkan oleh lingkungan sekolah dan sekutu yang berdekatan semacam ini (Whitehead, 1957: 17).

Guru RA itu merupakan teladan keberhasilan bagi pendidikan Islam anak usia dini yang berkarakter, berakhlakul karimah, memiliki etos kerja, bahkan dianggap sebagai orang yang sangat berperanan dalam meraih tujuan pendidikan RA yang merupakan cerminan mutu pendidikan dimasa depan. Pelaksanaan tugas dan kewajiban guru RA tidak terlepas dari pengaruh dalam dirinya maupun di luar yang membawa dampak pada perubahan keberhasilan guru RA berprestasi di Yogyakarta (Wawancara dengan ibu Sri Ngadiyati, S.Pd.AUD., guru RA Masyithoh Kantongan B Merdikorejo Tempel Sleman, pengalaman mengajar selama 35 tahun, sebagai guru berprestasi juara I tingkat wilayah DIY dan juara II di tingkat Nasional, wawancara pada tanggal 20 Oktober 2019).

Setiap individu guru RA tentunya berkeinginan untuk memperoleh predikat sebagai guru RA berprestasi, karena hal itu disamping sebagai sebuah kepuasan batin bagi dirinya, juga mendapatkan hadiah baik berupa uang, diberikan beasiswa untuk melanjutkan jenjang pendidikannya, studi banding ke satuan pendidikan luar negeri, bahkan sampai diumrahkan. Seorang guru yang diajukan terpilih untuk mengikuti kompetisi guru berprestasi biasanya guru dalam berorganisasi sangat aktif, sering mengikuti dan menjadi peserta pelatihan di mana-mana, banyak agendanya terlibat sebagai fasilitator dalam banyak pelatihan, memiliki 
setumpuk penghargaan yang berupa piagam maupun sertifikat, serta memiliki portofolio yang tebal. Dengan kata lain ditonjolkan hal-hal yang prosedural administratif (Wawancara dengan ibu Ifa, teman mengajar sekelas atau guru pendamping kelas RA B2 dari guru berprestasi peringkat 2 Nasional tahun 2017 (ibu Sri Ngadiyati), pada 26 Oktober 2019).

Menampik argumentasi umum para guru RA yang belum pernah memperoleh prestasi, maka terjawab oleh penyataan guru RA berprestasi yang telah dua kali mengikuti ajang kompetisi serupa, mengatakan bahwa:

"Guru berprestasi itu yang mampu menjadi rahmat di RA-nya. Sosoknya mampu menjadi teladan maupun inspirasi bagi rekan guru lain bahkan peserta didiknya. Guru yang tidak kikir berbagi ilmu serta pengalamannya kepada guru sejawat atau sahabat agar semuanya bisa maju serta berkembang. Dengan ungkapan lain, kebermanfaatannya di RA benar-benar terasa nyata. Jangan sampai guru banyak terlibat pada aktivitas di luar, sementara tupoksi atau tugas pokok serta fungsinya mengajar di kelas terbengkalai dan terlantar peserta didiknya. Beban tanggungjawab secara psikologis sebagai guru RA berprestasi itu berat, sebab disamping harus memiliki kompetensi di atas guru RA pada umumnya, juga harus mampu menjadi figur teladan, serta mampu membuktikannya melalui kinerja nyata dalam penguasaan mengajar di kelas" (Wawancara dengan Rufiyati Ambar Ningrum, pada 26 Oktober 2019).

Terbukti dalam keseharian guru RA berprestasi berangkat masuk sekolah lebih dahulu yaitu mulai pukul 07.00 WIB bahkan lebih awal dari itu untuk mempersiapkan perlengkapan pembelajaran sampai pukul 11.15 WIB ditambah dengan pelajaran tambahan guna mempersiapkan peserta didik masuk SD sampai jam 12.30 WIB. (Observasi pembelajaran kepada Guru berprestasi I yang mengajar di kelas RA B2 di RA Masyithoh Kantongan B Merdikorejo Tempel Sleman, pada tanggal 20 November 2019). Dalam pengertian paling sederhana, guru yaitu seseorang yang kegiatannya mengajar (Departemen Pendidikan dan Kebudayaan, 2006: 570).

Anton Ariyadi menyatakan bahwa mengajar adalah pekerjaan profesional karena menggunakan teknik dan prosedur yang berpijak pada landasan intelektual yang dipelajari dengan sengaja, terencana dan dipergunakan demi kemaslahatan umum, dalam hal ini anak didik RA. Sementara kinerjanya guru RA yaitu usaha dan kemampuan guru RA untuk melakukan tugas belajar mengajar sebaik-baiknya dalam perencanaan kegiatan pembelajaran dan pelaksanaan program pembelajaran serta evaluasi program pembelajaran (guru berprestasi 
juara harapan I tingkat wilayah DIY tahun 2017, pengalaman mengajar selama 5 tahun dari RA Baitur Rahmah Jl. Sawitsari A-15 Gang Anggrek Condongcatur Depok Sleman, wawancara pada tanggal 20 Oktober 2019). Kinerja guru RA yang dicapai berpedoman pada standar kompetensi profesional selama melakukan tanggung jawab sebagai guru RA.

\section{METODOLOGI}

Kajian ini perlu dilakukan langkah-langkah penelitian di antaranya: Jenis dan Pendekatan, hal ini dipilihnya kualitatif menjadi jenis penelitian dipakai peneliti dengan menggunakan pendekatan psikologis. Penelitian kualitatif memilki karakteristik antara lain: alamiah, menggunakan metode kualitatif, manusia menjadi instrumen, analisa data induktif, adanya fokus, deskriptif, lebih mengutamakan prosedur daripada produk, adanya kriteria menjadi keabsahan data, hasil penelitian dipertimbangkan dan disepakati bersama dan desain penelitian bersifat sementara. Taylor dan Bogdan mengartikan metodologi kualitatif menjadi prosedur penelitian yang melibatkan data deskriptif tertulis maupun kata-kata lisan terhadap orang-orang ataupun informan yang dapat diamati (Moleong, 2005: 3). Peneliti berusaha mengetahui arti peristiwa dalam kaitannya dengan objek penelitian dan situasi penelitian. Pendekatan ini memberi arahan pada makna interpretatif terhadap peristiwa-peristiwa kehidupan guru di sekitar RA. Lexy J. Moleong (2005:9) menyebutkan dengan istilah "verstehen". Peneliti berusaha mendekatkan diri ke dalam ranah konseptual obyek penelitian, sehingga pengertian substansial dapat dikembangkan di sekitar wilayah kehidupan sehari-hari di sekitar RA. Dalam penelitian kualitatif, pendekatan psikologis merupakan salah satu teori pendekatan penelitian, melalui memahami dan mendeskripsikan hal yang terjadi pada diri obyek penelitian. Pendekatan psikologis yang dilakukan lebih menekankan pada perilaku kehidupan seseorang, sehingga disebut juga dengan penelitian kualitatif yang menekankan pada keutuhan dan kedalaman data dari obyek yang diteliti, atau juga disebut penelitian naturalistik, karena situasi lapangan penelitian bersifat natural dan dinyatakan apa adanya. Penelitian ini bersifat deskriptif analitik, karena penelitian ini berupaya menguraikan situasi yang diteliti dalam wujud uraian naratif, di mana masalah pokok penelitian menjadi fokus penelitian (Nasution, 2003: 29-31), sementara diuraikan dalam wujud naratif dengan memaparkan uraian-uraiannya bersifat analisis. 


\section{HASIL DAN PEMBAHASAN}

Kinerja guru yang merupakan keberhasilan serta kompetensi atau kemampuan guru dalam menjalankan tugas-tugas pembelajaran yang ditunjukkan oleh dimensi: 1) kemampuan menyusun rencana pembelajaran, 2) kemampuan melaksanakan pembelajaran, 3) kemampuan melaksanakan jalinan antar pribadi, 4) kemampuan melakukan peneilaian atau assessment hasil belajar, serta 5) kemampuan melaksanakan program pengayaan dan remedial (Supardi, 2013: 18-19). Guru RA yang mempunyai kinerja yaitu guru yang mempunyai wawasan keilmuan yang mantap, pemahaman pembelajaran, wawasan sosial yang luas, bersikap positif terhadap pekerjaannya, dan menunjukkan prestasi kerja sesuai kriteria kinerja yang dipersyaratkan. Kinerja guru menjadi keberhasilan dan kemampuan guru dalam menjalankan berbagai tugas pembelajaran (Wawancara dengan Anton Ariyadi pada tanggal 20 Oktober 2019).

Sangat strategis bagi seorang pendidik apabila mengamati minat dari peserta didiknya. Hal ini sejalan dengan yang diungkapkan oleh Des Griffin (2014: 286) bahwa: There is compelling and important evidence about early childhood. Their interest, intrinsically creative, and they respond to encouragement and stimulation. Maksudnya ada bukti yang meyakinkan dan penting tentang anak usia dini. Anak-anak muda beragam dalam minat mereka, secara intrinsik kreatif dan mereka menanggapi dorongan dan stimulasi.

Terkait kinerja guru dalam melakukan program pembelajaran, terkandung tugas keprofesionalan guru ada dalam pasal 20 (a) perihal tugas guru Undang-undang RI tahun 2005 nomor 14, Tugas keprofesionalan guru yaitu: merencanakan pembelajaran, melaksanakan proses pembelajaran yang bermutu, serta menilai dan mengevaluasi hasil pembelajaran. Undang-undang Republik Indonesia No. 14 Tahun 2005. Pasal 20 tentang Guru dan Dosen. Sementara menurut Nana Sudjana (2005: 19), kinerja guru terlihat dari keberhasilannya di dalam meningkatkan sistem dan hasil pembelajaran, yang meliputi: 1) merencanakan program pembelajaran, 2) mengelola dan melakukan proses pembelajaran, 3) manilai kemajuan proses pembelajaran, serta 4) Menguasai bahan pelajaran.

Suharsimi Arikunto (2003: 243) juga berpendapat bahwa kinerja guru bisa dilihat dari aktivitas mengajar yang dilakukan dengan prosedur yang sesuai, yaitu dengan: 1) membuat 
perencanaan mengajar, berupa: mempelajari wawasan keilmuan yang akan diberikan atau ketrampilan yang akan didemonstrasikan atau dipresentasikan dalam kelas, menyusun persiapan tertulis, menyiapkan media, atau alat-alat pengajaran yang relevan, membuat alat evaluasi, 2) Melaksanakan pengajaran dalam kelas, mencakup: membuka atau menutup, menyampaikan penjelasan, memberikan peragaan, mengoperasikan alat-alat pembelajaran serta alat bantu lain, menyajikan pertanyaan, menyampaikan jawaban, melakukan kegiatan remedial maupun pengayaan, 3) melaksanakan penilaian hasil belajar, berupa pelaksanaan kuis (pertanyaan singkat), melaksanakan tes tertulis, mengoreksi, memberikan skor, menentukan nilai akhir.

Proses Pembelajaran menjadi inti dari kegiatan dalam satuan pendidikan di sekolah. Agar proses pengajaran berjalan dengan lancar salah satunya dengan menggunakan prosedur yang tepat dalam mengajar. Sehubungan dengan fungsinya selaku pendidik, pengajar, dan juga pembimbing, maka dibutuhkan adanya berbagai peranan yang terdapat pada diri individu guru (Wawancara dengan Anton Ariyadi pada tanggal 20 Oktober 2019). Sebagaimana yang diuraikan peranan guru di antaranya; guru selaku pemimpin kelas, pengajar, perencana, pembimbing, ekspeditor, pengatur lingkungan, partisipan, konselor supervisor, dan juga sebagai motivator (Usman, 2005: 10-11). Peranan-peranan yang dikemukakan tersebut yang dianggap mendominasi serta dapat diklasifikasikan menjadi sebagai berikut:

1. Guru selaku demonstrator, hendaknya memahami materi atau bahan pengajaran yang akan disampaikan dan senantiasa menumbuhkannya dalam arti mengembangkan kemampuannya dalam kaitannya dengan ilmu yang dikuasainya karena hal ini sangat menentukan hasil pembelajaran yang hendak diraih peserta didik.

2. Guru selaku pengelola kelas, sementara tujuan khususnya yaitu meningkatkan potensi peserta didik dalam memakai alat-alat pembelajaran, menyiapkan segala kondisi untuk membantu mereka bekerja serta belajar, ataupun menolong agar mereka dapat memperoleh hasil yang dikehendaki.

3. Guru menjadi fasilitator dan mediator, selaku mediator guru diharapkan mempunyai pemahaman dan pengetahuan yang cukup perihal media pendidikan sebab media atau alat pendidikan yang menjadi alat komunikasi agar mengefektifkan sistem pembelajaran. 
4. Guru selaku evaluator, dalam kegiatan sistem pembelajaran guru hendaknya sebagai seorang evaluator yang terampil. Maka jelaslah guru diharapkan terampil dan mampu melakukan penilaian atau assessment, karena dengan penilaian itu guru mampu mengetahui prestasi yang diperoleh peserta didik setelah menjalankan proses pembelajaran (Usman, 2005: 10-11).

\section{Aspek-aspek Kinerja Guru RA Berprestasi di Yogyakarta}

Berikut ini ada beberapa aspek kinerja bagi guru RA dalam melakukan proses pembelajaran, di antaranya meliputi hal-hal berikut:

1. Menggunakan metode, alat atau media, dan bahan pembelajaran

a. Menggunakan Metode Pembelajaran

Penggunaan metode belajar mengajar lebih efektif berdasarkan tujuan khusus yang hendak dicapai. Demikian pula kesesuaiannya dengan bahan pelajaran. Antara tujuan, bahan dan metode dituntut adanya keserasian (Nurdin dan Usman, 2003: 94). Apabila telah ditentukan suatu tujuan khusus, maka permasalahan berikutnya bagi seorang guru RA yaitu menetapkan suatu teknik yang memberikan tanggungan tertinggi akan tercapainya tujuan itu sebaik-baiknya, misalnya dengan sains sederhana untuk anak-anak (Wawancara dengan Anton Ariyadi pada tanggal 20 Oktober 2019).

Faktor yang perlu dipahami bagi seorang guru RA berprestasi dan profesional dalam hal menggunakan metode mengajar senada dengan yang dikatakan oleh Anton Ariyadi sebagai berikut:

"Metode mengajar disesuaikan dengan tujuan, juga disesuaikan dengan anak didik atau kemampuan anak-anak RA, kegiatan mengajar diserasikan dengan lingkungan, dan kegiatan pembelajaran terkoordinasikan dengan baik".

Metode pembelajaran yang efektif sesuai dengan tujuan dan kemampuan peserta didik telah dipilih oleh guru RA berprestasi dalam mengenalkan berbagai jenis binatang buas dan sejenisnya digunakanlah metode bercakap-cakap dan umpan balik pertanyaan dengan mengelompokkan peserta didik penuh kearaban sebagaimana gambar berikut: 


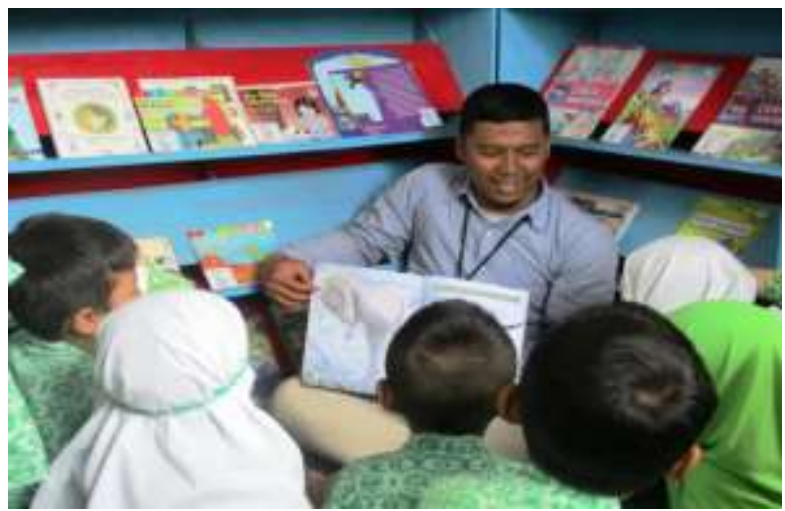

Gambar 5: Bapak Anton Ariyadi, S. Si. (guru berprestasi 4) sedang mengajar di sudut perpustakaan.

Guru berprestasi juga melakukan pembelajaran dalam mengenalkan jenis binatang peliharaan dengan melihat langsung, menyentuh, membelai binatng tersebut seperti binatang kucing agar peserta didik lebih dekat mengenalnya seperti gambar berikut:
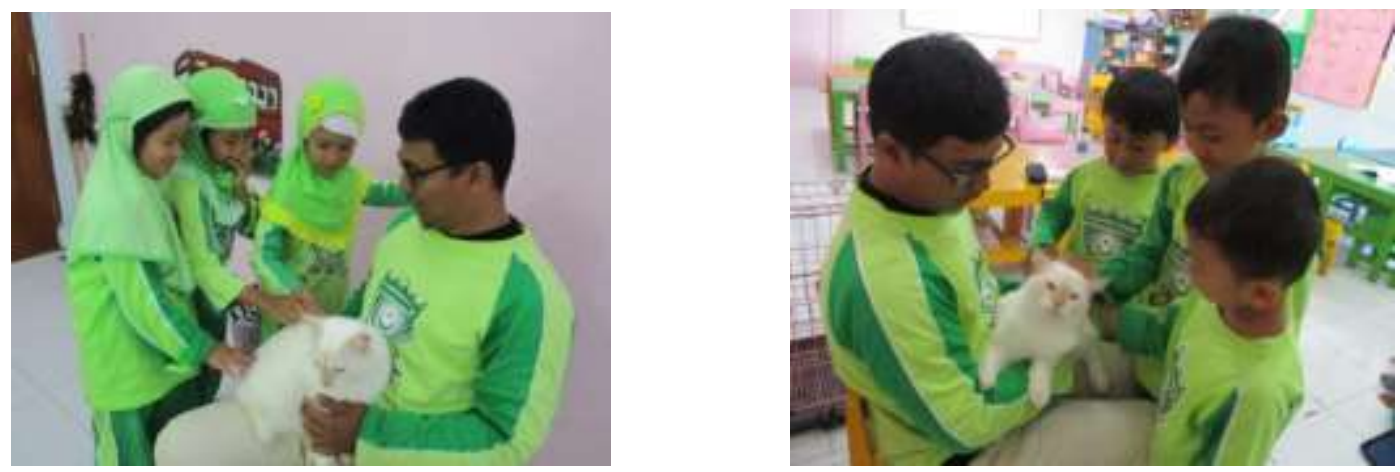

Gambar 6: Bapak Anton Ariyadi membawakan langsung binatang kucing anggora untuk dipertunjukkan secara langsung kepada peserta didik putrid an peserta didik putra.

b. Menggunakan Alat atau Media Pembelajaran

Alat atau media pengajaran yaitu seluruh alat yang dapat mendukung keefektifan serta efisiensi pengajaran. Alat pengajaran sering pula diartikan oleh sebagian orang dengan istilah sarana belajar atau sarana pengajaran. Alat pengajaran ini dapat mempengaruhi perilaku siswa sebab alat pengajaran tersebut juga terkandung unsur dari sumber pengajaran. Alat pengajaran itu ada yang sifatnya umum, dapat dipakai dalam segala bidang studi, ada pula yang dibuat tertentu untuk bidang studi khusus. Sebagaimana diungkapkan oleh Syafruddin Nurdin, dalam implementasi kurikulum dan guru profesional, sebagai berikut: Yang bersifat umum misalnya papan tulis, papan planel, papan agnetic (papan putih), serta akasis. Berkenaan dengan alat pengajaran yang didesain secara khusus untuk pelajaran atau bidang studi tertentu seperti: kerucut, kubus, jajaran genjang, dan balok yang terbuat dari kayu untuk pengajaran 
matematika, untuk bidang studi PAI umpamanya elemayer untuk tretasi, labu takar untuk pengeceran, avemeter untuk mengukur tahanan dan arus listrik, gelas kimia, barometer untuk mengukur suhu, serta pipet tetes (Nurdin dan Usman, 2003: 96).

Fungsi media atau alat dalam proses belajar bukan sekedar sebagai alat yang dipakai oleh guru, tetapi juga mampu mengkomunikasikan pesan kepada peserta didik. Intinya guru yang mempunyai kinerja profesional ialah mereka yang menggunakan media-media tersebut sebagai sarana untuk memotivasi dan berkomunikasi dengan peserta didik agar lebih efektif (Wawancara dengan Anton Ariyadi pada tanggal 20 Oktober 2019).

Tujuan pembelajaran dapat diraih secara maksimal, hal ini bisa diwujudkan dengan hasil belajar atau prestasi belajar anak didik yang tinggi. Media tidak prestasi belajar hanya berupa perabot keras atau hardware tetapi juga dapat berupa perangkat lunak (software). Hardware maupun Software dalam pelaksanaan proses pembelajaran bisa dipadukan, sebab hardware adalah mesin yang digunakan untuk menyajikan program misalnya: teaching mechine, tape recorder radio, tv, video cassettes, slide, film, overhead transparances dan sebagainya. Disamping berbagai media elektronik di atas, dapat pula digunakan media sederhana antara lain: poster, grafik, dan sejenisnya.

Media pembelajaran secara efektif, efisien, sekaligus sebagai sumber belajar atau pengajaran, guru RA berprestasi melakukan eksperimen sederhana dalam mengenalkan benda-benda cair seperti air yang memiliki sifat serta bentuknya mengikuti media yang ada. Misalnya air di tempat atau wadah yang berbentuk kotak, di botol, di gelas, maka air akan mengikuti bentuk serupa dengan tempatnya tersebut, seperti gambar di bawah ini:

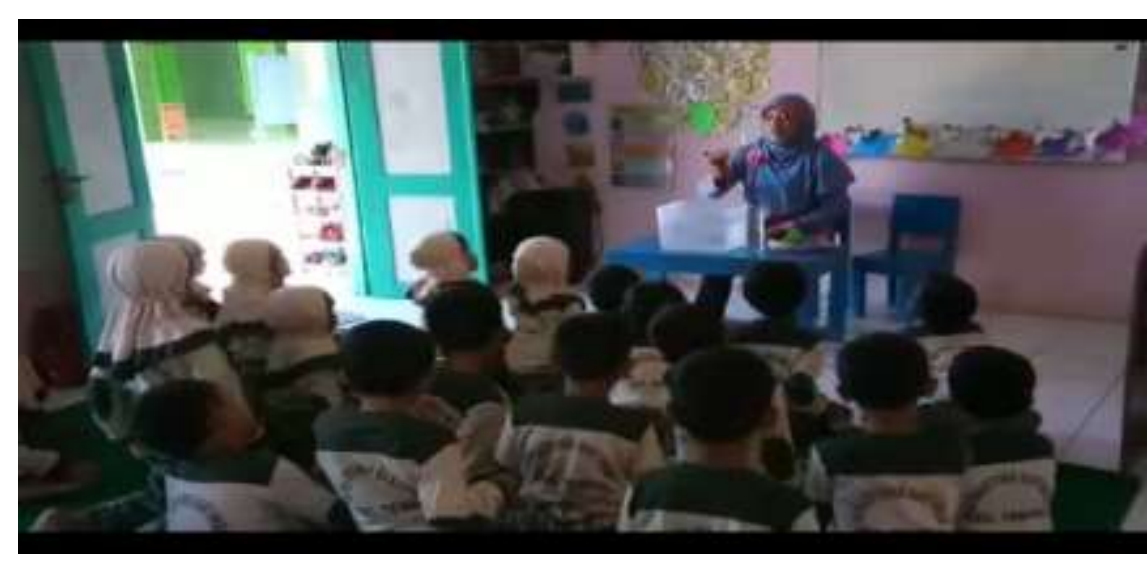

Gambar 7: Ibu Sri Ngadiyati, S.Pd.AUD. (guru berprestasi 1) sedang mengenalkan benda cair seperti air, dan benda padat seperti batu, kayu, besi, beserta sifat-sifatnya. 


\section{c. Bahan Pembelajaran}

Content atau materi pembelajaran hendaknya menjadi komponen kurikulum yang amat penting. Content menyangkut jawaban terhadap pertanyaan, apakah yang akan diajarkan?. Content ini sering kali tidak diperhatikan. Biasanya tinggal diambil saja dari buku teks yang berlimpah-limpah ketersediaannya, tanpa menghubungkannya dengan tujuan kurikulum, tujuan pendidikan, dan atau dengan tujuan instruksional (Nurdin dan Usman, 2003:102).

Jadi, langkah yang diambil oleh seorang guru RA berprestasi dalam memahami maupun menyampaikan materi yang disesuaikan dengan tujuan pendidikan, tujuan kurikulum, atau dengan tujuan instruksional. Dengan demikian, cara kerja seorang guru RA berprestasi dalam mempergunakan materi pelajaran dapat diklasifikasikan berdasarkan tujuan pendidikan, yakni ranah kognitif (mencakup: pemahaman, pengetahuan, penerapan, analisis, sintensis, evaluasi), afektif (menerima, merespon, dan karakteristik nilai, serta menghargai organisasi,) dan ranah psikomotor.

Terlebih guru RA berprestasi yang satu ini melakukan pembelajaran dengan bermain sains sederhana yaitu roket tenaga udara, seperti gambar berikut:
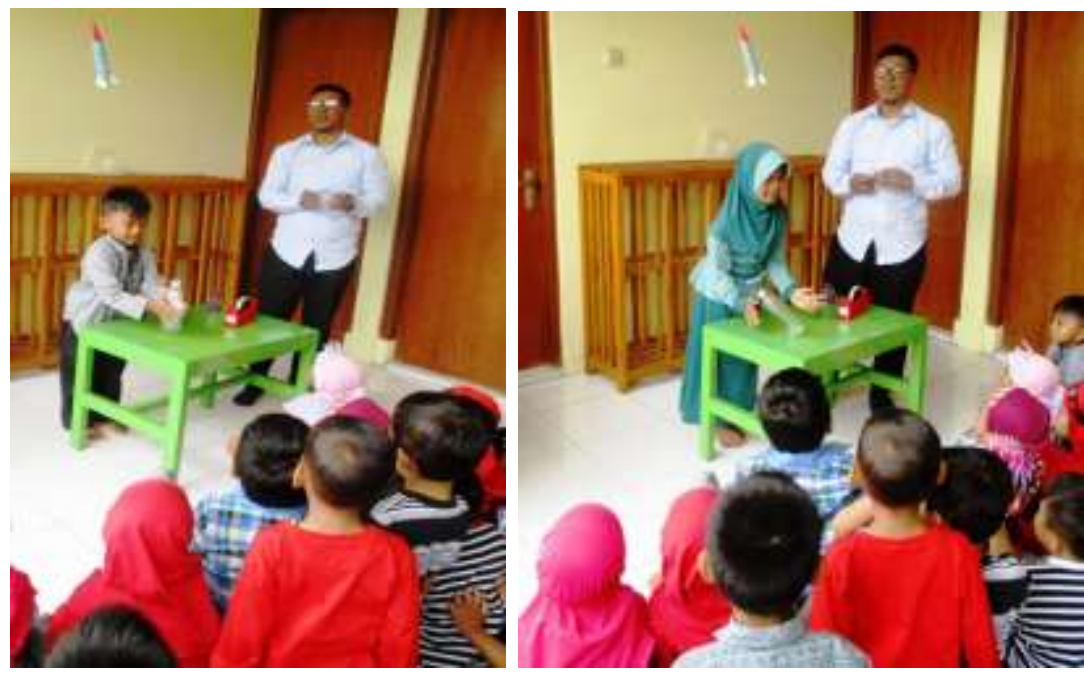

Gambar 8: Bapak Anton Ariyadi sedang mengajar dengan mengenalkan sains "bermain roket tenaga udara" sekaligus anak putra dan putri mempraktikkannya.

2. Mendorong dan mengoptimalkan partisipasi peserta didik

Dalam ssstem atau proses pembelajaran, Aspek kompetensi memotivasi dan menggalakkan keikutsertaan peserta didik dalam sistem pembelajaran ini terdiri dari: 
a. Menggunakan prosedur yang mengaktifkan peserta didik pada awal proses atau sistem pembelajaran (guru mampu menarik perhatian, memotivasi, memberi acuan, mengaitkan topik sebelumnya, membantu mengingat kembali pengalaman yang lalu, menggugah minat baru, dan membantu siswa mengerti apa yang akan mereka capai dengan keaktifan diri dalam kegiatan belajar).

b. Memberi kesempatan pada anak didik untuk ikut andil berperan dalam proses Pembelajaran (memberi kesempatan untuk merespon atau menanggapi dan berinisiasi atau berpendapat/opini). Ini dimanifestasikan oleh guru berprestasi dalam pembelajaran bercerita menggunakan atau melalui media boneka tangan seperti gambar berikut:
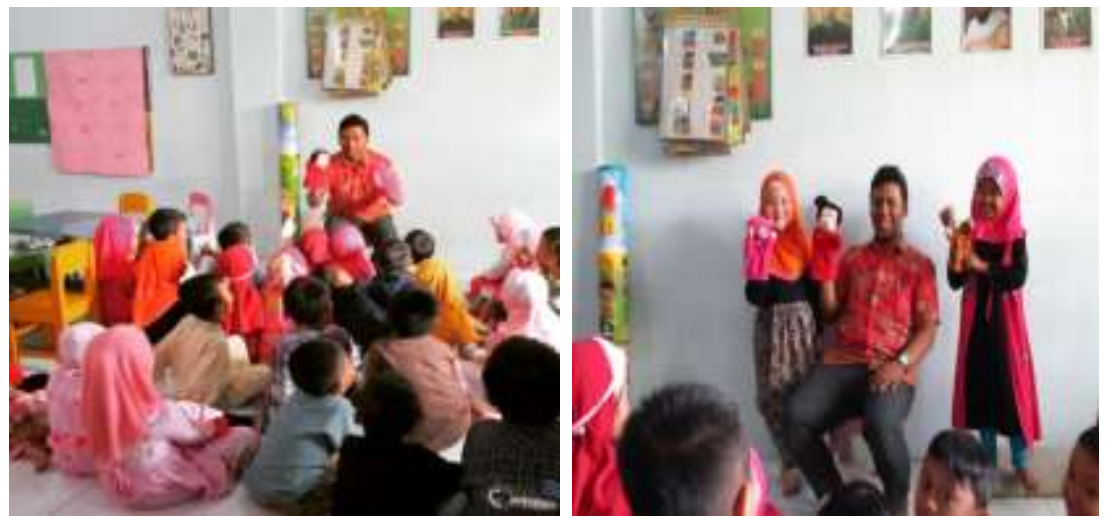

Gambar 9: $\begin{aligned} & \text { Bapak } \\ & \text { Anton Ariyadi }\end{aligned}$
medang
bercerita dengan
menggunakan media
boneka tangan, dan
peserta didik putri
mencobanya.

c. Memelihara keikutsertaan anak didik dalam proses belajar dan mengajar (meliputi penyediaan lembar kerja, mengajukan banyak pertanyaan, menghargai jawaban yang tepat dan mengarahkan yang tidak tepat, mengadakan permainan dan simulasi peranan, memantau kemajuan anak, dan membantu peserta didik berfikir kritis dalam memecahkan masalah

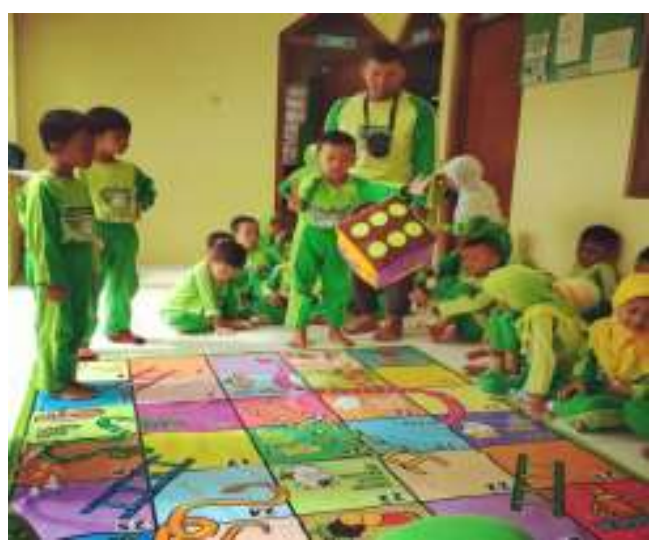

Keterlibatan peserta didik ini terjadi sebagaimana guru RA berprestasi melakukan pengajaran dalam aktivitas permainan ular tangga seperti gambar berikut dalam Gambar 10: Bapak Anton Ariyadi sedang melakukan pengajaran dengan melibatkan peserta didik secara aktif untuk mengenalkan sportifitas dengan bermain ular tangga. 
d. Menguatkan upaya siswa untuk memelihara keterlibatan dalam proses belajar mengajar (menetapkan kegiatan yang memungkinkan, memvariasi stimulasi, merespon partisipasi siswa, membangkitkan perhatian siswa, memberi kesempatan bertanya, menanggapi atau mengkritik, serta memperhatikan reaksi keterlibatan siswa baik non verbal maupun verbal.

Begitu juga yang dikerjakan oleh guru RA berprestasi melibatkan peserta didiknya dalam partisipasi permainan ular tangga guna memperhatikan reaksi verbal maupun non verbal dari peserta didik seperti gambar berikut:
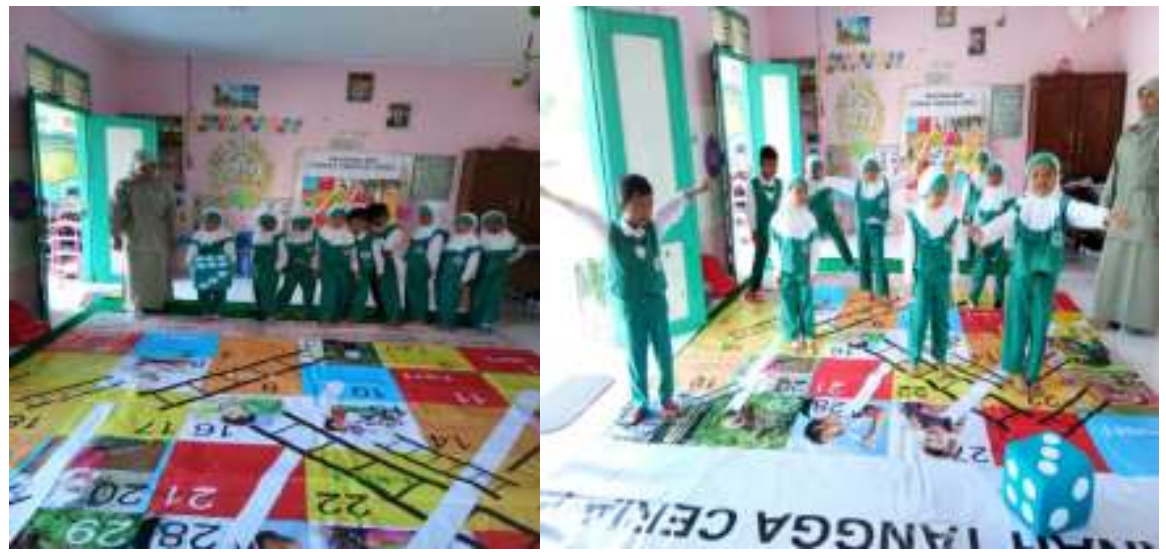

Gambar 11: Ibu Sri Ngadiyati (guru berprestasi 1) sedang memberikan instruksi mekanisme atau cara bermain ular tangga dan sekaligus mempraktikkannya.

Kegiatan awal sekali dan utama yang memberikan semangat baru bagi peserta didik yaitu saat memasuki tempat belajar yang menyenangkan mulai dari kedatangannya anak-anak disambut oleh ibu guru di depan gerbang pintu masuk sebagaimana guru RA berprestasi melakukan penyambutan terhadap anak-anak yang sedang memasuki pintu masuk seperti pada gambar berikut:

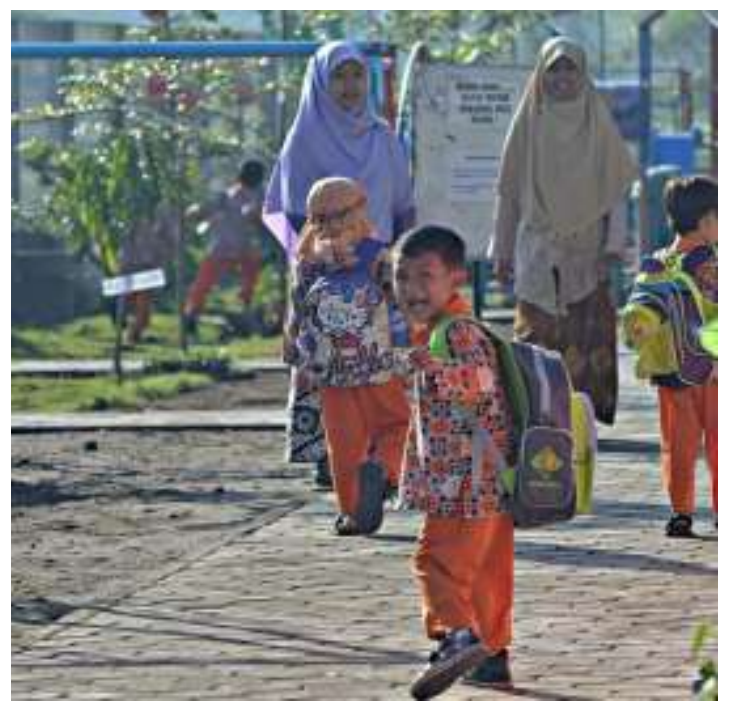

Gambar 12: Ibu Rufiyati Ambar Ningrum, S. Sos.I. (guru RA berprestasi 3) sedang menyambut peserta didik yang mengkondisikan dirinya dan peserta didik telah berada dalam lingkungan sekolah.

Kemudian setelah penyambutan kepada peserta didik dilakukan oleh guru RA berprestasi mengadakan upacara pengebaran bendera merah putih sebagai pembina upacara guru RA 
berprestasi mengajarkan kepada peserta didik akan cinta tanah air kelahirannya melalui serangkaian kegiatan upacara sepertigambar berikut ini:

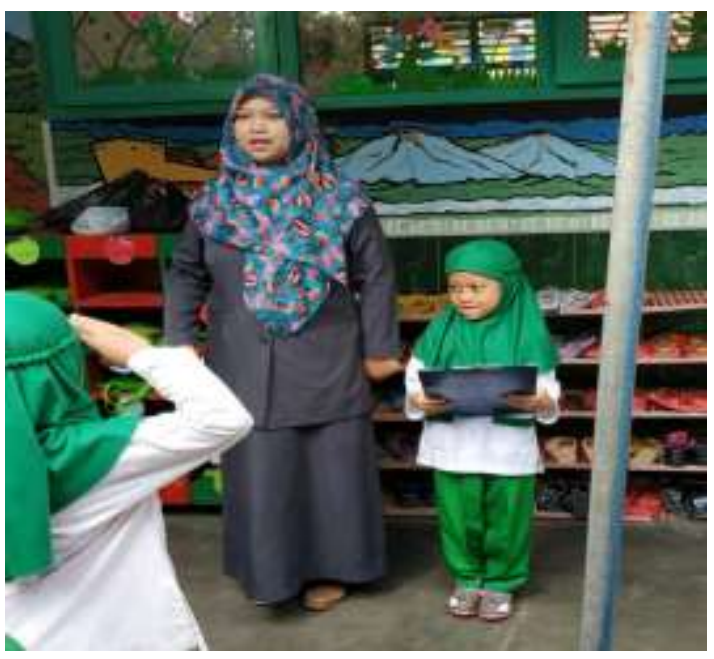

Gambar 13: Ibu Estri Ritah Indriwati, S.Pd.I. (guru RA berprestasi 2) sedang menjadi pembina upacara.

$$
\text { Selanjutnya dalam menguatkan }
$$

upaya peserta didik untuk memelihara ketertiban dalam sistem pembelajaran yang mmperhatikan reaksi baik non verbal maupun verbal, guru RA berprestasi berikut telah mengajarkan bagaimana mmusatkan perhatian dengan berolah raga pada posisi kepala diangkat untuk merenggangkan otototot leher dan pundak sebagaiman gambar berikut:

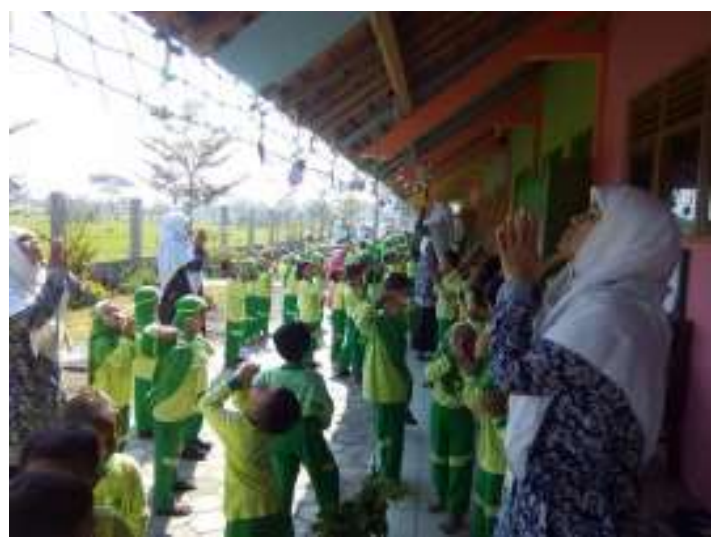

Gambar 14: Ibu Rufiyati Ambar Nigrum (guru RA berprestasi 3) sedang mempraktekkan gerakan olahraga pada perenggangan otot leher dengan kedua jari jempol nempel pada ujung dagu guna rileksasi dan konsentrasi.

3. Mengorganisasikan waktu dalam prosedur pembelajaran

Dalam aspek kompetensi ini, para pengajar diharapkan mampu memanfaatkan secara maksimum waktu pembelajaran yang telah dialokasikan. Untuk kepentingan tersebut ada sejumlah unsur aktifitas yang perlu diperhatikan dan ditampilkan oleh pengajar agar waktu dapat digunakan secara efisien yakni:

a. Memulai pembelajaran dengan tepat waktu

b. Melanjutkan pelajaran sampai habis waktu yang dialokasikan.

c. Menghindari penundaan waktu yang tidak dibutuhkan selama pengajaran berlangsung. 
d. Menghindari penyimpangan topik yang tidak diperlukan.

e. Sikap siswa yang keras ditanggapi dengan memadahi.

f. Daya persentase memperhitungkan reaksi-reaksi yang tidak diharapkan dan para siswa (Nurdin dan Usman, 2003: 112).

Kinerja bagi seorang guru yang berprestasi baik, tentunya guru RA berprestasi mampu memanaj dan menggunakan waktu yang telah tersedia. Misalnya saja memulai di awal pelajaran tepat waktunya serta meneruskan sampai habis waktunya. Kemudian penyampaian materi tidak keluar bahkan menyimpang jauh, dan juga tidak melewatkan waktunya begitu saja. Penyampaian materi dengan LKA (lembar Kerja Anak) guru RA berprestasi ini menyampaikan tema pengenalan diri sendiri yang berkaitan dengan keadaan jasmaniah pengenalan nama-nama anggouta badan, nama-nama saudara terdekat serumah mulai dari: bapak, ibu, kakak, adik, nenek, kakek, dan seterusnya seperti gambar di bawah ini:

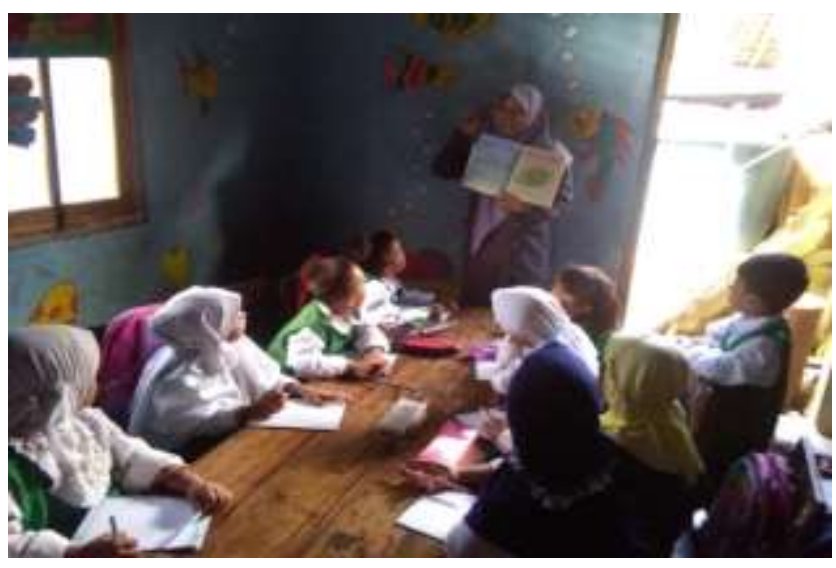
Gambar 15: Ibu Rina Wahyuni, S. Pd. AUD. (guru RA berprestasi 5) sedang menerangkan pengenalan diri sendiri dengan menggunakan media LKA (Lembar Kerja Anak).

Begitu pula ketika waktu istirahat guru RA berprestasi memperkenalkan beberapa permainan out door yang dimiliki dan ada di lingkungan sekolah khususnya RA Masyithoh Janten Temon Kulon Progo agar bermain secara tertib bergantian dan bekerjasama antar teman bermain, berikut gambarnya:

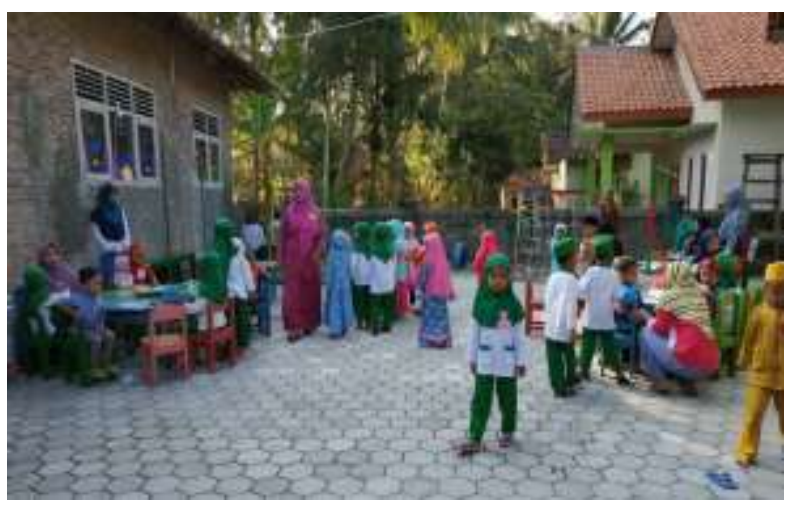

Gambar 16:

Ibu Estri Ritah Indriwati, S.Pd.I. (guru RA berprestasi 2) sedang memperkenalkan beberapa permainan out door kepada peserta didiknya agar bermain tertib dan bergantian untuk mengisi waktu istirahat. 
4. Melakukan penilaian atau assessment hasil belajar dalam proses pembelajaran.

Beberapa aktifitas yang perlu dilakukan oleh pengajar dalam menilai pencapaian siswa selama pembelajaran berlangsung adalah 1) Penilaian pada permulaan (pre-test) proses pembelajaran, dimaksudkan agar guru RA berprestasi mampu mengenal kesiapan peserta didik terhadap bahan atau materi pengajaran yang telah disampaikan, yang hasilnya akan dipakai untuk menetapkan strategi mengajar. 2) Penilaian proses pembelajaran untuk mendapat balikan terhadap tujuan yang dicapai. 3) Penilaian pada akhir (post-test) proses pembelajaran untuk memahami capaian siswa terhadap tujuan yang ditentukan. Hal ini cocok dengan apa yang diungkapkan oleh Sri Ngadiyati bahwa assessment atau diagnosis diadakan pada beberapa frase yakni: 1) pada permulaan proses instruksional, 2) selama proses mengajar, dan 3) pada akhirnya (Wawancara dengan Gupres1 (ibu Sri Ngadiyati), pada tanggal 6 Oktober 2019).

\section{Pengukuran Kinerja Guru RA Berprestasi}

Berkaitan dalam hal pengukuran kinerja guru RA berprestasi ini ada dua tugas guru yang bisa dijadikan sebagai standar pengukuran kinerja guru RA berprestasi, yaitu tugas yang berkaitan terhadap proses pembelajaran dan tugas yang berhubungan dengan penataan, serta perencanaan tugas-tugas pembelajaran (Uno dan Lamatenggo, 2012: 65-66). Mengacu pada dua tugas tersebut, maka terdapat tiga kriteria pokok yang berhubungan dengan kinerja guru, yaitu proses, karakteristik-karakteristik guru, dan hasil atau produk (perubahan sikap siswa). Dalam proses pembelajaran, kinerja guru RA berprestasi dapat dilihat pada kualitas kerja yang dilakukan berkaitan dengan kegiatan belajar mengajar yang mengacu pada kompetensi guru yang professional.

Lebih lanjut, dalam mengukur kinerja guru RA berprestasi yaitu dengan; menguasai bahan, mengelola proses pembelajaran, penguasaan kelas, memanfaatkan sumber belajar atau media pembelajaran, menguasai dasar-dasar pendidikan, merencanakan program pengajaran, menguasai kelas, mengelola interaksi pembelajaran, melakukan penilaian hasil belajar siswa, memanfaatkan berbagai metode dalam pembelajaran, memahami dan melaksanakan fungsi dan layanan bimbingan penguluhan, memahami dan menyelenggarakan administrasi sekolah, 
serta dapat menafsirkan dan memahami berbagai hasil temuan penelitian dalam pengembangan mutu pembelajaran.

\section{Standar Pengukuran Kinerja Guru RA berprestasi}

Berdasarkan uraian pengukuran kinerja guru RA berprestasi di atas, bahwa kinerja guru RA berprestasi mempunyai 5 (lima) dimensi. Hal ini dapat diuraikan sebagaimana tabel berikut ini, yaitu:

\begin{tabular}{|l|l|}
\hline \multicolumn{1}{|c|}{ Dimensi } & \multicolumn{1}{c|}{ Indikator } \\
\hline Kualitas kerja & $\begin{array}{l}\text { 1. Memahami bahan, } \\
\text { 2. Memenaj atau mengelola proses pembelajaran, } \\
\text { 3. Mengelola kelas. }\end{array}$ \\
\hline $\begin{array}{l}\text { Kecepatan/ketepat } \\
\text { an kerja }\end{array}$ & $\begin{array}{l}\text { 1. Memanfaatkan sumber belajar atau media, } \\
\text { 2. Menguasai dasar-dasar pendidikan, } \\
\text { 3. Merencanakan program pengajaran. }\end{array}$ \\
\hline $\begin{array}{l}\text { Inisiatif dalam } \\
\text { kerja }\end{array}$ & $\begin{array}{l}\text { 1. Menguasai kelas, } \\
\text { 2. Mengatur interaksi pembelajaran, } \\
\text { 3. Mengelola penilaian hasil belajar. }\end{array}$ \\
\hline Kemampuan kerja & $\begin{array}{l}\text { 1. Menggunakan berbagai metode Pembalajaran, } \\
\text { 2. Melaksanakan serta memahami fungsi maupun layanan bimbingan } \\
\text { penyuluhan. }\end{array}$ \\
\hline Komunikasi & $\begin{array}{l}\text { 1. Menyelenggarakan dan memahami administrasi sekolah, } \\
\text { 2. dapat menafsirkan dan memahami berbagai hasil temuan penelitian } \\
\text { dalam pengembangan mutu pembelajaran. }\end{array}$ \\
\hline
\end{tabular}

Ada dua strategi penting yang dilaksanakan untuk mengembangkan kinerja guru RA berprestasi yaitu: pelatihan dan motivasi kinerja. Pelatihan digunakn untuk menangani rendahnya kompetensi guru, sedangkan dorongan kinerja digunakan untuk menyelesaikan rendahnya gairah atau semangat kerja. Intensitas penggunaan kedua strategi tersebut tergantung dari kondisi guru itu sendiri. Bahkan jika memang diperlukan, keduanya dapat dilakukan secara simultan (Barnawi dan Mohammad Arifin, 2014: 80).

Program pelatihan yang diberikan berdasarkan kebutuhan, artinya jenis pelatihan yang direncanakan sesuai dengan jenis kemampuan apa yang masih rendah. Pelatihan diberikan oleh guru guna mempermudah guru dalam menjalankan pembelajaran terkait dengan tugas pekerjaannya. Sasaran pelatihan bagi guru adalah menguasai pengetahuan, dan ketrampilan, 
serta perilaku yang diharapkan pada program-program pelatihan maupun penerapannya ke dalam aktifitas sehari-hari. Pernyataan lain bahwa kegiatan pelatihan yang efektif yaitu kegiatan pelatihan yang mengarah kepada 3 (tiga) ranah atau domain, yaitu: kognitif, dan afektif, serta psikomotorik. Selain itu pelatihan diterapkan dalam kegiatan guru RA, baik internal maupun eksternal RA atau sekolah (Lijan Poltak Sinambela, 2012: 17).

Pemberian pelatihan itu bermanfaat bagi para guru RA terutama untuk meningkatkan ketrampilan, pengetahuan dan kemampuan secara professional. Hal ini sesuai juga dengan pernyataan Raymond dkk (2014: 271): bahwa tujuan pelatihan yaitu agar karyawan memiliki pengetahuan, perilaku, dan keterampilan, yang ditekankan dalam pelatihan dan menerapkannya pada hari-hari mereka: "the goal of training is for employees to master the knowledge, skills, and behaviours emphasized in training and apply them to their day-today".

Ada berbagai macam bentuk pelatihan yang diselenggarakan, baik pelatihan internal di sekolah ataupun pelatihan eksternal yang dilakukan di luar sekolah. Pelatihan yang diadakan di dalam sekolah dan diadakan setiap pekan diberikan oleh tim training mentoring ataupun rekan kerja yang mengikuti pelatihan di luar sekolah. Sedangkan pelatihan di awal atau pertengahan tahun ajaran diberikan oleh lembaga lain. Bentuk-bentuk pelatihan yang diselenggarakan bermacam-macam yaitu in house training, peer teaching, e-learning. Hal ini sesuai dengan pernyataan Byars and Rue (2003: 192-194), several methods can be utilized to satisfy an organization's training needs and accomplish its objective. The more commonly know methods include classroom training, apprenticeship training, and job rotation. (Berbagai metode yang dipergunakan untuk memenuhi kebutuhan pelatihan organisasi dan mencapai tujuannya. Metode yang lebih umum dikenal meliputi: pelatihan kelas, pelatihan pemagangan, dan rotasi pekerjaan).

\section{SIMPULAN}

Dalam rangka untuk meningkatan kinerja guru RA berprestasi ini, paling tidak Anton Ariyadi telah mengemukakan ada 6 (enam) langkah bisa dikerjakan oleh guru RA berprestasi yaitu: 1) Mengetahui masih ada kekurangan dalam kinerja, 2) Mengenal kelemahan dan kekurangan dalam keseriusan mengajar, 3) Mengidentifikasi perihal apa yang merupakan 
penyebab kekurangan terlebih yang behubungan dengan kinerja itu sendiri, 4) Mengembangkan rencana kinerja yang tersaji, 5) Melakukan penilaian masalah tersebut sudah teratasi ataukah belum (problem solving), serta 6) Memulai dari awal lagi, apabila diperlukan dan dibutuhkan kembali.

Peningkatan kinerja guru RA berprestasi ini mempunyai hasil karena semuanya mempunyai kekurangan dan kelebihan, hal itu sangat berguna bagi para guru RA, dan dari berbagai uraian teori tentang kinerja guru RA berprestasi, maka kinerja guru RA berprestasi yang dimaksud yaitu kemampuan seseorang guru RA berprestasi untuk melaksanakan tugas sebagai guru RA yang menghasilkan temuan memuaskan guna terpenuhinya tujuan organisasi dalam kelompok satuan pendidikan atau unit kerja yaitu RA. Kinerja guru RA terkait hal ini bisa diukur melalui 4 unsur, yaitu kinerja guru RA berprestasi dalam merencanakan pembelajaran, kinerjanya dalam hal usaha melakukan pembelajaran, kinerja guru dalam menilai pembelajarannya, serta kinerja guru RA berprestasi dalam kedisiplinan tugas pembelajarannya atau yang lain.

\section{DAFTAR PUSTAKA}

Arikunto, Suharsimi. (1993). Manajemen Pengajaran Secara Manusiawi. Jakarta: Rineka Cipta.

Barnawi. dan Mohammad Arifin. (2014). Kinerja Guru Profesional: Instrumen Pembinaan, Peningkatan, \& Penilaian. Yogyakarta: Ar-Ruzz Media.

Byars, Lloyd L., Leslie W. Rue. (2003). Human Resource Management. Singapore: McGrawHill.

Departemen Pendidikan dan Kebudayaan. (2006). Kamus Besar Bahasa Indonesia. Jakarta: Balai Pustaka.

Griffin, Des. (2014). Education Reform: The Unwinding of Intelligence and Creativity. Newyork: Springer.

Moleong, Lexy J. (2005). Metodologi Penelitian Kualitatif. Bandung: Remaja Rosdakarya.

Nasution, A. (2003). Metode Penelitian Naturalistik Kualitatif. Bandung: Tersito.

Noe, Raymond A., John R. Hollenbeck, Berry Gerhart \& Patrick M. Wright. (2014). Human Resources Management. Singapore: McGraw-Hill.

Nurdin, Syafruddin. dan M. Basyiruddin Usman. (2003). Guru Profesional dan Implementasi Kurikulum. Jakarta: Ciputat Press.

Sinambela, Lijan Poltak. (2012). Kinerja Pegawai: Teori Pengukuran dan Implikasi. Yogyakarta: Graha Ilmu. 
Smith, Jhonathan A. (2013). Dasar-dasar Psikologi Kualitatif: Pedoman Praktis Metode Penelitian. Terj. Khozim, M. Bandung: Nusa Media.

Sudjana, Nana. (2005). Dasar-dasar Proses Belajar Mengajar. Bandung: Sinar Baru Algensindo.

Supardi. (2014). Kinerja Guru. Jakarta: Raja Grafindo Persada.

Suryosubroto, B. (2005). Proses Belajar Mengajar di Sekolah. Jakarta: Rineka Cipta.

Undang-undang Republik Indonesia. (2005). No. 14 Tahun 2005. Pasal 20 tentang Guru dan Dosen. Diakses 22 November 2019, http://luk.staff.ugm.ac.id/atur/UU142005GuruDosen.pdf.

Uno, Hamzah B. dan Nina Lamatenggo. (2012). Teori Kinerja dan Pengukurannya. Jakarta: Bumi Aksara.

Usman, Moh. Uzer. (2006). Menjadi Guru Profesional. Bandung: Remaja Rosdakarya.

Whitehead, Alfred North. (1957). The Aims of Education and Other Essays. New York: The New American library. 